\title{
Taking partly-free voters seriously: Autocratic Response to Voter Preferences in Armenia and Georgia
}

\section{Matteo Fumagalli}

School of International Relations

University of St Andrews

Arts Building

The Scores

St Andrews KY16 9AX

Scotland, United Kingdom

Email: mf29@st-andrews.ac.uk

\section{Koba Turmanidze}

Caucasus Research Resource Center Georgia

1 Ramaz Chkhikvadze Street

0179 Tbilisi

Georgia

Email: koba@crrccenters.org

\begin{abstract}
Do voters matter in competitive authoritarian regimes and, if so, how? Do their preferences make any difference in the way in which the regime conceives policies and goes about policy-making? In this article we show that they do, and that incumbents take them seriously. Crucially, the way the regime responds to policy demand determines their durability in office. In this article we explain why, despite strong similarities, the political regime ruling Armenia remained stable over the years (from the mid-1990s), whereas the one in Georgia has been unseated on two occasions (2003-04; 2012-13). Evidence confirms that policy-making and the voters' perceptions thereof also play an important role in determining whether a regime collapses or survives. The incumbents collect information on voter preferences, and devise policies in response to them. Policy-making thus matters and is extremely consequential. Paradoxically, however, policy-making makes a difference in counter-intuitive ways. The article concludes that a regime which refrains from making grand promises, or blatantly contradictory or unrealistic ones, has greater chances of surviving than those that set out to transform society, like Saakashvili's Georgia. Ultimately, such policies backfire on those who launched them.
\end{abstract}




\section{Introduction}

'We had conceptual disagreements. They [the leadership of the United National Movement that left the party] were doing surveys and saying that people want to hear about this, these are popular issues for the people and we should develop a program which does not irritate people by talking about something else. ... I think very differently: you should not trudge behind the processes, should not follow the current, because only dead fish drift along with the current. You should be ready to swim against the current. The direction of the current may change, but your direction should never change.'

Mikheil Saakashvili (President of Georgia, 2004-2013) ${ }^{1}$

Despite considerable western political and financial support, as well as an increase in both state capacity and - to a lesser extent - organizational power, Mikheil Saakashvili's Georgia went through several phases of instability. At times, this instability was tackled through extensive reliance on coercion, such as in 2007-2008 (Berglund 2013). The ruling party's increasingly erratic - if grandiose in rhetoric and scale - policy-making paved the way to its own demise, brought about by the defeats in the 2012 parliamentary and 2013 presidential elections. By contrast, Armenia's political elites - most notably former President Robert Kocharian (1998-2008) and President Serzh Sargsyan (2008-present) - managed to secure regime stability, despite far greater protests (Babayan 2015). Even the latest wave of opposition-driven protests in 2016 failed to unseat the incumbent (Novikova 2017).

That the regime in Armenia responded to voters' preferences differently from that in Georgia and that its response affected its capacity to sustain its power, whereas Georgia experienced far greater instability, raises a number of questions which we explore in this special issue of Caucasus Survey. Do voters matter in competitive authoritarian regimes? If so, how exactly? Do their preferences make any difference in the way in which the regime thinks and goes about policies and policy-making? The contributions in this special issue show that they do, and

\footnotetext{
${ }^{1}$ New.on.ge (2017).
} 
that incumbents take them seriously. Crucially, the way the regime responds to policy demand determines their durability in office. Evidence provided in the individual articles show that organizational power matters (in the form of state capacity, party strength and cohesion), and so does resorting to important levels of patronage (the pork barrel during elections). And yet, policymaking and the voters' perceptions thereof also play an important, if understated, role in determining whether a regime collapses or survives.

We are interested in understanding why, despite strong similarities, the political regime ruling Armenia remained stable over the years (from the mid-1990s), whereas the one in Georgia has been unseated on two occasions (2003-04; 2012-13). The articles shed light on how public policy influences political stability and instability. A common thread throughout the special issue is that despite some strong similarities (increased state capacity, willingness to rely on repression and co-optation) such divergent paths can be explained by the regimes' policy choices and the divergent regime-voter dynamics these engendered. In Armenia, policies have been changing incrementally and hence, producing small gains or losses to large segments of the electorate. In contrast, Georgia's ruling party launched large-scale transformative policies in 2004, which left sizable sections of the electorate dissatisfied. Thus, we argue that transformative policies increase voter dissatisfaction and contribute to the electoral defeat of the regime, whereas incremental policy change helps the regime to consolidate power through elections.

In other words, we show that authoritarian regimes do much more than survive or collapse (Art 2010; Fumagalli 2017; Pepinsky 2013). They collect information on voter preferences, and devise policies in response to them. Policy-making thus matters and is extremely consequential. Paradoxically, however, policy-making makes a difference in counter-intuitive ways. As Armenia's case shows, a regime which refrains from making grand promises, or blatantly contradictory or unrealistic ones, has greater chances of surviving than those that set out to transform society, like Saakashvili's Georgia. Ultimately, such policies backfire on those who launched them.

The articles included in this special issue of Caucasus Survey are the result of a collaborative project of Armenian and Georgian researchers, which examined regime-voter linkages and interactions in the South Caucasus. The project was conducted with the support of the Academic Swiss Caucasus Net (ASCN). 


\section{Key concepts and definitions}

Of the various sub-types of authoritarianism, competitive authoritarian regimes have received a large amount of attention in recent years for a number of reasons, ranging from the availability of data, the possibility of conducting field research, and the more meaningful role of some authoritarian institutions (elections, parties, parliaments) compared to non-competitive regimes (Brancati 2009; Gandhi and Lust-Okar 2009). As scholarly conversations proceed in waves, after an initial interest in typologies (Linz 1974, 2000; Brooker 2013; Ezrow 2011), attention has seemingly cemented around the study of democratic-looking institutions, such as elections, parties and parliaments. Three elements of authoritarian institutions have received particular attention: their origins (why were they created in the first place?), how they operate (do they work differently from democracies?), and their effects (what purposes do they serve? Do they help maintain regime stability or do they foster change?) (Pepinsky 2013). In particular, the work of Magaloni (2008) and Gandhi (2008) on elections under authoritarian rule, of Brownlee (2007) about the degree of institutionalization of specific (party) organizations, and that of Brancati on the mechanisms through which elites retain power (2009) have done much to "dispel the notion that institutions such as parties, elections, and legislatures are exclusive to democracies" $(2009,2.12)$ or that they amount to mere window-dressing.

Following Levitsky and Way's seminal work on the topic, we understand competitive authoritarian regimes as "civilian regimes in which formal democratic institutions exist and are widely viewed as the primary means of gaining power, but in which incumbents' abuse of the state places them at a significant advantage vis-à-vis their opponents. Such regimes are competitive in that opposition parties use democratic institutions to contest seriously for power, but they are not democratic because the playing field is heavily skewed in favour of incumbents. Competition is real but unfair" $(2010,5)$. Both Armenia and Georgia fit in this definition well and have tended to fit in this regime sub-type for a large part of the post-Soviet period; according to Freedom House, Armenia and Georgia mostly remained in the 'partly free' category of countries (Freedom House 2017). This trend is largely confirmed by the Polity IV scores, where both countries have been 'stuck' between democracy and autocracy since attaining independence from the Soviet Union (Polity IV project 2015). 
[graphs 1 and about 2 here]

Our main dependent variable is the regime's political stability. We define stability as the regime's ability to secure electoral victory for the incumbent or his designated political successor. We treat the incumbent's electoral failure as political instability, though this may or may not lead to regime change. As we are interested in the factors that help sustain regime stability or cause regime instability and change, in our contributions we do not directly discuss the factors promoting or hindering democratization, since electoral change of the incumbent may or may not change regime type. One article in this special issue addresses the impact of state capacity on political stability. We define state capacity as the state's ability to mobilize resources to implement the public policies it chooses and operationalize them through the estimation of relative political extraction, estimated based on actual extraction divided by predicted extraction (Arbetman-Rabinowitz et al. 2012, 17).

In competitive authoritarian regimes, voters have poor accountability mechanisms at their disposal: since the incumbent creates and retains a competitive advantage in elections, voters can do very little to hold elected officials accountable for their promises. Hence, voters become disillusioned with political participation, which is reflected in low partisanship and low levels of political participation. The disillusionment of voters creates an incentive for political parties, including the incumbent, to come up with vague and often contradictory promises to bring voters back to the polling stations. Such repeated interactions between the voters and parties create an accountability trap: voters cannot hold their elected officials accountable for their promises due to the ambiguity of promises and become further disillusioned with political participation.

While incumbents of competitive authoritarian regimes enjoy the benefits of an uneven playing field, they know they can be ejected from office. One way incumbents can stave off this outcome is providing goods to elites, who can deliver votes, to keep them inside their coalition; a second is providing goods to all such as property rights or public education (Bueno de Mesquita et. al, 2003). However, goods given to the public, when they result from reform, create a mass of instant losers followed by winners over time. If a would-be reformer wants to retain office, they need to maintain the coalition which brought them there, meaning there must be more winners than losers. Given that elections are always approaching, reformers face a dilemma. If they cannot create more winners than losers before elections through reform, then they must coerce or co-opt those who 
select them, both elites and regular voters, or lose office. However, if reformers do choose to stay in office through less than savoury means, it is also likely that they have entered a self-defeating game, through the resulting volatility in state capacity. Co-opting elites before elections takes resources away from investing in state capacity, and hence the ability to deliver goods. Through the fluctuation in delivery of goods to elites and the general public, each group will become uncertain of whether they can expect goods in the future. Stemming from this uncertainty, a credible challenger can enter the electoral playing field and unseat the incumbent.

\section{Competitive non-democratic rule in the South Caucasus}

The countries of the South Caucasus provide an interesting vantage point from which to observe the functioning of competitive authoritarian regimes and the effects of policy-making on regime stability/instability. Apart from a limited period in the early 1990s during which some limited pluralism existed, Azerbaijan has emerged as an increasingly closed and non-competitive authoritarian regime centred around the exploitation of natural resource wealth and the establishment of a rentier economy (Radnitz 2012). As such, it can only offer very limited insights into the debates at hand. By contrast, Armenia, Georgia, and even the de facto states of Abkhazia, Nagorny Karabakh and, to a very limited extent, South Ossetia, have experienced various degrees of political instability.

For good reasons, much of the analysis on the region has been driven by research on conflict and the role of external powers explicitly (e.g. Babanyan 2015; Gammer 2008, Green and Waters 2010, Geukjian 2012; Oskanien and Oskanian 2013, Saparov 2015) or indirectly, when examining nationalism and identity politics (e.g Ayoob and Ismaiylov 2015; Kemolidze, Moore, Smith and Yemelianova 2014). In particular, the works of Zürcher (2007), de Waal (2010), and Jones (2010) have significantly enriched our understanding of conflictual dynamics in the region and the interaction between regional and external powers. Substantively, the contributions to this special issue differ from much of the scholarship on the South Caucasus in that they take a step back from the focus on nationalism, war and conflict and the role of international powers. This is not because we deny their importance, but rather we feel that a fuller understanding of the politics of the region 
needs to take into consideration domestic policy-making and the linkages between domestic actors, and specifically elites and voters (Broers, Iskandaryan and Minasyan 2015). More needs to be said about the role of local elites and especially the citizens of the two countries, their preferences and more generally the interaction between autocratic leaders and voters. This is especially true for Georgia and Armenia, as we demonstrate in the various articles, but this holds true for the de facto states as well. Abkhazia, Nagorny Karabakh and South Ossetia have, in this order, expressed varying - even increasing - degrees of competitive politics. Karabakh's performance in terms of political rights and civil liberties seems to be stronger than the parent state (Caspersen 2011; Smolnik 2012; Kolstø and Blakkisrud 2012). Whether this tantamounts to timid democratization (von Steindorff 2012; Ó Beacháin 2012), hybrid governance (Protsyk 2012) or patronage politicscum-dominant party systems (Ishiyama and Batta, 2012) is of course a matter of debate. All the same, in unequal measure, all of them have experienced some degree of contestation in elections, though this is more evident in Abkhazia than in the others (consequently, Abkhazia is also the de facto state that has received greater scholarly attention in this regard, see Ó Beacháin, 2012 and 2015). More generally, though, there is much more going on inside the de facto states than just 'surviving' and seeking recognition (Ó Beacháin, Comai and Tsurtsumia-Zurabashvili 2016; Broers, Iskandaryan and Minasyan 2012). We know elections are contested and that transfer of power has occurred as a result of electoral victories/defeats. What should be examined in greater detail is the extent to which electoral fraud played any role in the electoral process and whether it influenced the outcome in any significant way. The logic of the voters should also be subject to empirical investigation. Moreover, elections aside, other aspects of competitive authoritarianism (Levitsky and Way's 'arenas of contestation') (media, judiciary, legislative) have not been subject to comparable levels of scrutiny, with attention concentrating primarily - and predictably - around question of (non-)recognition, de facto statehood and state-building (von Steindorff 2012), and the relationships with the parent and kin states. Consistent both with our findings about the importance of organizational power and the insights of the literature on authoritarian durability (Brownlee 2007; Magaloni 2007), the establishment and institutionalization of political parties has considerably helped boosting the regime's ability to remain in power, as Ishiyama and Batta have noted with regard to several de facto states, also beyond the post-Soviet space (2012). Protsyk's work on on Transnistria' also sheds considerable insights on the sources of regime stability and instability in the de facto states (2012). Although we hope that scholars will build on the work on 
policy-making and regime-voter linkages in competitive authoritarian regimes developed in this special issue to other states in the region and the post-Soviet space more broadly, in this special issue we focus on Armenia and Georgia as they offer sufficient variation on the dependent variable. As such, the contributions build on and expand some of the themes touched on in Wooden and Stefes on transition politics (2012) and opportunities for and obstables to democratization (Berglund 2013; Babayan 2015; Mac Ginty 2013), including corruption and patronage (Stefes 2006; Kupatadze 2016; Nasuti 2016). As we delve into the domestic politics of Armenia and Georgia we shed light on various aspects that affect regime stability and instability: voters' policy preferences, voting behaviour; the role of state capacity; the regime's reliance on coercion, legitimation and co-optation; quality of elections and the incumbent's accountability trap. We discuss these issues in turn.

\section{Are partly free voters policy-blind?}

The importance of elections in competitive authoritarian regimes is widely acknowledged in the literature. They can serve as both a self-legitimation tool as well as an instrument to oust the incumbent. Needless to say, voters are often assumed to be of tertiary importance in less than democratic contexts - the regime can manipulate, buy, or outright steal their votes. We challenge this view using evidence from Armenia and Georgia, showing that voters have stable preferences that are grounded in significant economic problems, such as poverty and inequality in each country. Moreover, observational and experimental evidence confirm that policies do matter for the incumbent: voters' assessments are positively related to their chances of being re-elected. Also, voters respond to different policy proposals differently.

Significant challenges related to poverty reduction and stagnant inequality have been reflected in perceived economic conditions as shown in the Caucasus Barometer surveys: unemployment has been the main concern of the populations in both countries at around 45 percent

in Armenia and 50 percent in Georgia (CRRC 2008-2015). Likewise, 60 percent perceive themselves as unemployed in each country during the past 10 years, while approximately 30 percent sought a job unsuccessfully (CRRC 2008-2015). 
The stability of people's grievances reflect substantial economic difficulties in both countries: Armenia and Georgia experienced large economic declines at the dawn of their independence: from 1990 to 1994 GDP dropped by 51 percent in Armenia and by 72 percent in Georgia (World Bank 2016a, 2016b). Economies started recovering in the mid-1990s with incremental growth in both countries, which accelerated in the 2000s reaching 12 percent in Armenia and 8 percent in Georgia on average until the countries were hit by the 2008 global economic crisis (World Bank 2016a, 2016b). Still, economic growth did not translate into the reduction of either poverty or inequality: Georgia remained highly unequal with its GINI coefficient fluctuating around 0.4. While Armenia has been relatively more equal, the GINI coefficient has not moved below 0.3 (World Bank 2016a, 2016b). Moreover, although poverty has been declining in both countries since 2010, it remained substantial: 25 percent of the population earned less than USD 3.10 a day in Georgia and 15 percent in Armenia in 2014 (World Bank 2016a, 2016b).

What roles do voters assign to the government to solve their most pressing problems? The two countries differ significantly in this respect. In terms of political ideology, Armenian voters lean towards the left and Georgian voters towards the right: a majority of Armenian voters endorse increased state ownership of businesses, whereas a plurality of Georgian voters support increased private ownership of businesses (CRRC, 2013). This trend described above is confirmed by a survey experiment carried out in Tbilisi and Yerevan in the spring of 2016: voters in Yerevan were significantly more supportive to state intervention in the economy compared to voters in Tbilisi (Graph 3).

[graph 3 about here]

Correspondingly, people in Armenia have a much higher expectation that the state should solve people's problems than in Georgia: while a large majority of Armenia's population look to the government as the people's parent, Georgians are split almost equally on the question of whether government should take care of people like parents take care of their children or whether the people are the government's bosses and hence, should control it (CRRC 2015). Given stagnant economic conditions and the inability of politicians to significantly improve people's lives, how do we know that policies still matter for the electorate? If policies matter at all, do voters assess the incumbents' 
performance and make voting decisions accordingly? A 2016 survey experiment in Tbilisi and Yerevan helps to provide an answer to the first question (Turmanidze 2017), while analysis of retrospective voting in Georgia sheds light on the second (Babunashvili 2017).

Using the survey experiment we wanted to test whether voting, party support and expected vote share of the party would change following different policy promises by a hypothetical party. To this end, we randomly assigned one of four promises to respondents in each city: (1) an ambiguous promise to improve the economic situation in the country, (2) a state-driven promise increase taxes and increase state investments in job creation, (3) a market-driven promise decrease taxes and encourage private investments in job creation, and (4) an inconsistent promise - decrease taxes and increase state investments in job creation. The survey experiment showed that the type of promise had no effect on the decision to vote or not. In contrast, voters were not policy-blind in terms of party support: party support and expected vote share of the party varied depending on the type of policy it promised to implement. Voters in Armenia and Georgia responded differently to promises: whereas a state-driven promise significantly decreased both support and expected vote of the party in each city, the market-driven and the inconsistent promises were significantly less popular in Tbilisi compared to Yerevan. Considering the responses of all voters, an abstract promise was the safest option for the party in Tbilisi, while other types of promises would substantially decrease the party's expected vote share and party support. In Yerevan, the state-driven promise was the least beneficial for the party, while the market-driven promise appears to have had a sizable negative impact on expected vote share (graphs $4 \mathrm{a}$ and $4 \mathrm{~b}$ ).

[graphs 4a/FILE 4 and 4b/FILE 5 about here]

Interestingly, voters looked at the promises through the prism of their ideology. We crossreferenced four types of treatment with an index of state intervention composed of four survey items. Here again, we observe sharp differences between the cities: in Tbilisi, any promise works better than the abstract promise for the party if the voter highly supports state intervention in the economy. We did not find such impact in the case of Yerevan. As the survey experiment showed, policy promises matter for future support to the party, but do voters assess critically the 
incumbent's past performance to make a voting decision? In 'Retrospective voting in Georgia: Does the past matter?' Babunashvili shows that voters are engaged in retrospective voting. The article highlights that the most weighty issues for voters are related to the economic situation unemployment, wages, poverty, and the affordability of healthcare. Although to a much lesser extent, voters also care about government success in democracy-building and security-related issues. Babunashvili's analysis draws attention to a positive relation between voter support for the incumbent party and positive assessments of the government's policies in socio-economic, democracy, and security-related issues: Citizens who assess government policies negatively are more prone to voting for opposition candidates or not voting at all compared to those who are more satisfied with the government's performance. Notably, these findings are very similar for two different ruling parties that stood for very different policies in the country: The United National Movement (2008-2012), which largely focused on state building and administrative reform and the Georgian Dream - Democratic Georgia (2012-present), which introduced comprehensive health insurance and supported a greater role of the state in the economy compared to its predecessor.

Overall, we conclude that the content of policy matters for voters, shaping their political behaviour. We also found that the link between the policy and party support, as well as the impact of political ideology, is much stronger in Georgia than in Armenia. Furthermore, the case study of Georgia demonstrated that voters' decisions to vote for the incumbent are conditioned by their assessment of the governments' performance. But how do politicians decide on the content of specific policies and pace of policy change in order to meet voters' expectations? We look at this question in the next section.

\section{Anatomy of policy making in non-democracies}

Despite similarities in economic conditions, Armenia and Georgia followed very different paths of policy making in the 2000s. The ruling elite of Armenia incrementally changed policies, while in Georgia abrupt changes started after the Rose Revolution in most important policy areas, such as law enforcement, education, economic policy and more generally, public administration. What role did the different policymaking paths play in regime (in)stability? 
In competitive authoritarian regimes, the ruling elite engages with the electorate to address their needs and gain legitimacy. At the same time, the rulers should deal with non-ruling elites, powerful private interests outside government, which can mobilize voters for or against the incumbent regime. Hence, the ruling elite faces a dilemma to gain legitimacy through delivering policies that are good enough to keep their winning coalition together for the next elections. How do less than democratic regimes interact with non-ruling elites and the electorate in the process of making key policy choices?

We argue that in competitive authoritarian regimes radical shifts in public policy occur through incumbent state capture. Following Grzymala-Busse, we define incumbent state capture as the extraction of state resources by the elite for the sake of the political party (Grzymala-Busse 2008, 640). Yet incumbent state capture does not necessarily mean that the elite uses state resources for its private material gain only: rather, extracted resources are often applied to design institutions that distribute benefits to supporters (Grzymala-Busse 2008, 641). We add to this argument that the pace of policy making is conditioned by the ruling elite's approach to non-ruling elites: if the rulers decide to decrease the provision of private goods, they will need to move on reforming institutions very quickly and establish new mechanisms to sustain the monopolization of policy making. Such a fast attack on private interests upsets non-ruling elites and decreases the incumbent's chances of electoral success. Hence, the incumbent is motivated to initiate significant policy changes to shift the weight from private goods to public ones, in other words, launch policies that can produce more winners than losers. Yet, the dissatisfied non-ruling elite also works to mobilize voters against the incumbent by highlighting losses over benefits.

Gilbreath and Turmanidze's article in this special issue ('The self-defeating game: How state capacity and policy choice affect political survival') develops an argument about the reformer's dilemma. Drawing on Way's work on how autocratic stability is crucially linked to state power (2009) and building on selectorate theory (Bueno De Mesquita et al., 2003), the authors contend that the chance of the incumbent's party remaining in office is at least in part a function of the capacity of the state they hold power over. Analysing cross-country data for the past 40 years, the authors find that if the incumbents succeed in increasing state capacity, it increases their chances of staying in office. However, they argue, and the data shows that, the reformer should also be wary of volatility stemming from reform. Cross-country analysis is complemented by two case studies from the South Caucasus to illustrate these points: while Georgian state capacity 
developed in fits, jumps and starts, in Armenia state capacity developed at a slow and steady pace for most of its independence. As the aphorism goes, slow and steady wins the race with politicians being thrown out of office in Georgia and the incumbent in Armenia maintaining its power. Based on this analysis, the authors argue that a self-defeating game is at work for reformers.

As important as regime-voter and regime-elite interactions are we do not claim that these are the only issues that matter when it comes to accounting for why Armenia's competitive authoritarian regime has remained stable in the post-independence period, even in the face of strong opposition and protests, whereas Georgia has experienced a far greater degree of instability. To show how the incumbents' policy choice influences political continuity and change, Shubladze and Khundadze provide an overview of public policies in Armenia and Georgia over the past 15 years ('Balancing the Three Pillars of Stability in Armenia and Georgia'). As they do, they ground the article in Gerschewski's (2013) theoretical framework that views legitimation, repression, and co-optation as the three strategies or pillars of regime stability in less than democratic regimes. They describe a set of specific policies designed by ruling parties to gain legitimacy in the eyes of voters as well as policies aimed at co-optation and/or repression of political opponents. The authors demonstrate that the key to the incumbent's electoral survival is the complementary application of policies based on available resources as well as timing, organization and balance between pillars. Shubladze and Khundadze show how the Armenian government managed to balance the pillars of stability by effective and well-timed application of different policies, while the government of Georgia failed to use relevant pillars of stabilization when one of the other pillars did not work to the incumbent's advantage. Looking at concrete policies in the two countries, Georgia's fast economic reforms, including mass privatization, dissatisfied many citizens, whereas Armenia's ruling elite mostly engaged co-opted actors from outside the government in the policy making process. The authors also suggest that dissatisfaction of voters is hardly enough to defeat the ruler, but it creates a fertile ground for a viable challenger to put together a new winning coalition against the incumbent. The authors conclude that the policies of Armenia's ruling party have been more oriented towards elites, whereas Georgia's United National Movement, the ruling party between 2003 and 2012, launched a successful attack on elites to the detriment of their material and symbolic capital. World Bank Governance indicators provide support for this claim (World Bank 2016a, 2016b). Specifically, the control of corruption and government effectiveness indicators mark two different paths taken by rulers in Armenia and Georgia: while both indicators changed 
incrementally in Armenia through the 2000s, Georgia saw steep increases after the Rose Revolution though 2012 (Graph 5). Following Innes, we interpret control of corruption and government effectiveness as indicators of relative balance between the ruling party and private interests (Innes 2014, 89). Substantial increases in the control of corruption score together with comparable increases in the government effectiveness measure in Georgia show that the ruling party successfully defeated elite private interests, which cannot be observed in Armenia. However, both ruling parties in both countries responded to the voters' preferences in an autocratic way: Armenia slowly and steadily implemented policies to the benefit of private interests and maintained their winning coalition (PFA 2013). Georgia launched large-scale policy reforms, but as quoted in the epigraph of this article, swam "against the current." Consequently, UNM policies did not address voters most significant concerns, such as unemployment, poverty and overall quality of life (Rekhviashvili and Polese 2017). Hence, 'shall we eat the pavement?' became a popular anti-UNM slogan in the country.

[Graph 5/File6 about here]

\section{Consequences of autocratic responses to voter preferences}

Although elections have been held regularly in the South Caucasus and that, with the exception of Azerbaijan, competition has been real (even if not fair, as Levitsky and Way ((2010)) point out), surprisingly little has been written about the elections, and typically about individual electoral rounds (Berglund 2013; Fumagalli 2014; Mueller 2013). In fact, ironically and somewhat surprisingly, electoral politics in the de facto states has attracted greater attention than the competitive political dynamics in countries like Georgia and Armenia (Ó Beacháin 2015; Ishiyama and Batta 2012; Ó Beacháin 2012; von Steindorff 2011; Smolnik 2012).

Gilbreath and Balasanyan ('Elections and election fraud in Georgia and Armenia) fill in a gap in the literature, in that they offer a systematic - and rare - analysis of election day fraud. Elections on unfair playing fields are common. Yet election day fraud can result in authoritarians being thrown from office (Sjoberg 2016; Tucker 2007). In principle, the freer the environment, the more an authoritarian must rely on means other than election day fraud to retain office, because in 
such environments they are less capable of coercing the population without reaping greater repercussions. Among those other means is co-optation through public policy. In their article Gilbreath and Balasanyan explain this phenomenon using comparative case studies of election day fraud in Armenia and Georgia over time. To do so, the article uses methods from the field of election forensics to provide a quantitative comparison of the scale of election day fraud in each country's elections since 2007 using precinct-level election results for parliamentary and presidential elections. The test results suggest that Georgia's elections have had less election day fraud than Armenia's during this period. This finding provides a theoretical basis to explain why public policy has been a greater concern in Georgia than Armenia.

Public opinion echoes the findings of election forensics: It would not be an exaggeration to state that each election brought frustration to the Armenian voters during the past decade: a plurality has assessed election results as unfair and relatively few voters believed in the fairness of elections (as low as 9 percent in 2013). In contrast, assessments of election fairness by Georgian voters dramatically increased after the 2012 parliamentary elections to a record 56 percent and remained solid, around 40 percent after subsequent elections (CRRC, 2008-2015). Moreover, voters continued to appreciate democracy despite the ongoing failure of elected officials to address people's needs: a plurality of voters in each country reported in 2015 that democracy was preferable to any type of government (CRRC, 2015). However, it is worth noting that public support of democracy has declined in both countries: between 2011 and 2015 support to democracy decreased from 65 to 47 percent in Georgia and from 55 percent to 36 percent in Armenia (CRRC 2008-2015).

Declining support for democracy is related to decreasing trust in political parties, representative bodies and courts (CRRC 2008-2015). This signals voters' dissatisfaction and disillusionment with politics in both countries dubbed as an accountability trap in Turmanidze's article ('Promises, lies, and the accountability trap'). The author adopts an experimental design to examine whether voters support ambiguous pre-election promises in Armenia and Georgia and if so, what it tells us about accountability mechanisms and a potential accountability trap. The accountability trap emerges when voters cannot hold their elected officials accountable for their promises due to the ambiguity of promises and become disillusioned with political participation. Turmanidze's main finding is that abstract, ambiguous promises do not decrease either turnout or the respective party's support. Rather, if a party is not specific about its intended actions to meet 
the promise, it will do significantly better than a party promoting a specific state-driven policy option. A statistically weaker, but more optimistic finding is that voters do set a limit on politicians' fantasies: compared to the abstract promise, they punish the party which gambles with inconsistent policy options. These findings echo Svolik's (2013) two alternative paths of democratic development: whether 'bad' politicians undermine public support to democracy or 'good' politicians help to consolidate it through reinforcing voters' belief in accountability. Yet, the persistence of economic problems, mediocre performance of elected officials, declining trust in institutions, and decreasing appreciation of democracy hint at less optimistic paths for both countries.

\section{In lieu of a conclusion}

In sum, we intervene in the debates on comparative authoritarianism and the politics of the South Caucasus, where we see our contributions as five-fold. First, in terms of the 'big picture' we take up the challenge launched by Pepinsky (2013) to unpack the life of authoritarian regimes. As noted elsewhere (Art 2010; Fumagalli 2017) they certainly do more than just survive or collapse. We detail their policies as we seek to capture their impact on political stability (all articles) and the way their stability relates to state capacity (Gilbreath and Turmanidze). Second, we seek to provide a more dynamic framework to capture the linkages and interactions between elites and voters, paying special attention to the latter by looking at their expectations of the government, their policy preferences, and voting behaviour (Babunashvili; Gilbreath and Balasanyan). Third, as we build on the insights coming out of the institutional turn in comparative authoritarianism, we focus on authoritarian institutions at the micro-level and analyze how micro-institutions define who gets what and how much, i.e. how the regime uses institutions to coerce, co-opt and cooperate with significant political actors, including voters (Shubladze and Khundadze). By doing so, we offer an empirical application of Gerschewski's framework on the three pillars of stability as we examine the policies in the areas of repression, legitimation and co-optation and the interaction between these three pillars in depth, highlighting not only the shifts between use of a specific pillar but also the importance of the timing in doing so (Shubladze and Khundadze). Crucially, we show that what the incumbents promise and whether they lie, make grand and unrealistic promises or embark on entirely contradictory pledges, makes a difference as they cause an accountability trap 
(Turmanidze). Last, but not least, methodologically, this issue also seeks to contribute to the scholarship on the South Caucasus by complementing qualitative research with a more decisively quantitative and mixed-methods angle. This is still rare in research on the region ${ }^{2}$, including in work on electoral politics. In addition to official statistical data on elections and policies, the articles use primary micro-data on political polls from both countries to address voters' preferences, party identification and voting behavior. Moreover, the CRRC team carried out a survey experiment in both Armenia and Georgia in 2016 to study a specific aspect of voter-party linkage and its consequences for accountability. Statistical analysis is complemented with in-depth interviews with political observers and political actors from Armenia and Georgia and in-depth case studies and narratives that allow us to flesh out the causal mechanisms at play. To conclude, although competitive authoritarian regimes repond in a variety of ways to voters, those responses have crucial effects on political survival. Such regimes take voters seriously. So should we.

${ }^{2}$ For a notable exception see Driscoll, Berglund and Blauvelt (2016). 


\section{Bibliography}

Agadjanian, A., Jodicke, A. and E. van der Zweerde (eds). 2015. Religion, Nation and Democracy in the South Caucasus. London: Routledge.

Arbetman-Rabinowitz, M., J. Kugler, M. Abdollahian, K. Kang, H. T. Nelson, and R. L. Tammen. 2012. Political Performance. In The Performance of Nations, edited by Jacek Kugler and Ronald L. Tammen. Lanham: Rowman \& Littlefield Publishers, Inc.

Art, D. 2010. What do we know about Authoritarianism after ten years? Comparative Politics, 44, no. $3,351-373$.

Ayoob, M. and M. Ismayilov (eds). 2015. Identity and Politics in Central Asia and the Caucasus. London: Routledge.

Babayan, N. 2015. Democratic Transformation and Obstruction. EU, US, and Russia in the South Caucasus. London: Routledge.

Babunashvili, G. Retrospective voting in Georgia: Does the past matter? Caucasus Survey. In this issue.

Berglund, C. 2014. Georgia between Dominant-Power Politics, Feckless Pluralism, and Democracy. Demokratizatsiya: The Journal of Post-Soviet Democratization. 22(3):445-470

Brancati, D. 2012. Democratic Authoritarianism: Origins and Effects. Annual Review of Political Science, 17: 2.1-2.14.

Broers, L., A. Iskandaryan, and S. Minasyan. 2015. Introduction: the unrecognized politics of de facto states in the post-Soviet space. Caucasus Survey, 3(3), 187-194.

Brownlee, J. 2007. Authoritarianism in an Age of Democratization. Cambridge: Cambridge University Press.

Bueno de Mesquita, B., A. Smith, R. M. Siverson, and J. D. Morrow. 2005. The Logic Of Political Survival. Cambridge, MA: MIT Press.

Caspersen, N. 2012. Regimes and peace processes: Democratic (non)development in Armenia and Azerbaijan and its impact on the Nagorno-Karabakh conflict. Communist and post-Communist Studies, 45, 131-139.

CRRC. 2008-2015. Caucasus Barometer. Retrieved on 5 May 2017 from http:/caucasusbarometer.org/en/time-series/

CRRC. 2013. Caucasus Barometer. Retrieved on 5 May 2017 from http://caucasusbarometer.org/en/cross-country/

CRRC. 2015. Caucasus Barometer. Retrieved on 5 May 2017 from http:/caucasusbarometer.org/en/cross-country/

de Waal, T. 2010. The Caucasus: An Introduction. Oxford, Oxford University Press.

Driscoll, J., C. Berglund and T. Blauvelt. 2016. Language hierarchies in Georgia: an experimental approach. Caucasus Survey, 4(1), 44-62.

Freedom House. 2017. Freedom in the World. Retrieved on 5 May 2017 from https://freedomhouse.org/report/freedom-world/freedom-world-2017 
Fumagalli, M. 2016 Stateness, contested nationhood, and imperilled sovereignty: the effects of (non-western) linkages and leverage on conflicts in Kyrgyzstan. East European Politics 32, no. $3,355-377$.

Fumagalli, M. 2014. The 2013 Presidential Elections in Georgia. Electoral Studies, 35, 395-397.

Fumagalli, M. 2017. Social contention, authoritarian resilience, and political change. Democratization, online 23 November 2016. http://dx.doi.org/10.1080/13510347.2016.1259217

Gammer, M. (ed). 2008. Post-Soviet Disorder. Ethno-Nationalism, Islam and the State in the Caucasus. London: Routledge.

Gandhi, J. and E. Lust-Okar. 2009. Elections under Authoritarianism. Annual Review of Political Science, 12, 403-422.

Gandhi, J. 2008. Political Institutions under Dictatorship. New York, Cambridge University Press. George, J. 2009. The Politics of Ethnic Separatism in Russia and Georgia. Basingstoke: Palgrave. Gerschewski, J. 2013. The three pillars of stability: legitimation, repression, and co-optation in autocratic regimes. Democratization, 20, no. 1, 13-38.

Geukjian, O. 2012. Ethnicity, Nationalism and Conflict in the South Caucasus Nagorno-Karabakh and the Legacy of Soviet Nationalities Policy. Farnham: Ashgate.

Gilbreath, D. and S. Balasanyan, Elections and election fraud in Georgia and Armenia. Caucasus Survey. In this issue.

Gilbreath, D. and K. Turmanidze, The self-defeating game: How state capacity and policy choice affect political survival. Caucasus Survey. In this issue.

Green, J., Waters, C. (eds). 2010. Conflict in the Caucasus. Implications for International Legal Order. Basingstoke: Palgrave.

Grose, C.R. 2014. Field experimental work on political institutions. Annual Review of Political Science, 17, 355-370.

Grzymala-Busse, A. 2008. Beyond Clientelism. Incumbent state capture and state formation. Comparative Political Studies, 41(4/5), 638-673.

Hale, H. 2015. Patronal Politics. Eurasian Regime Dynamics in Comparative Perspective. Cambridge: Cambridge University Press.

Hyde, S.D. 2015. Experiments in International Relations: Lab, Survey, and Field. Annual Review of Political Science, 18, 403-424.

Innes, A. 2014. The political economy of state capture in Central Europe. Journal of Common Market Studies, 52(1), 88-104.

Ishiyama, J. and A. Batta. 2012. The emergence of dominant political party system in unrecognized states. Communist and post-Communist Studies, 45, 123-130.

Iskandaryan, A. 2015. In quest of the state in unrecognized states. Caucasus Survey, 3(3), 207218.

Jones, S. 2013. Georgia: A Political History Since Independence. London: IB Tauris.

Jones, S.F. (ed). 2010. War and Revolution in the Caucasus. Georgia Ablaze. London: Routledge 
Kemoklidze, N. C. Moore, J. Smith, G. Yemelianova. 2014. The Many Faces of the Caucasus. London, Routledge.

King, C. 2008. The Ghost of Freedom: A History of the Caucasus. Oxford: Oxford University Press.

Kolstø, P. and H. Blakkisrud. 2012. De facto states and democracy: The rise of Nagorno-Karabakh. Communist and post-Communist Studies, 45, 141-151.

Kupatadze, A. 2016. Georgia's break with the past. Journal of Democracy, 27(1), 110-123.

Levitsky, S. and L. Way. 2010. Comparative Authoritarianism. Hybrid Regimes after the Cold War. Cambridge: Cambridge University Press.

Mac Ginty, R. 2013. Hybrid Governance: The Case of Georgia. Global Governance, 19(3), 443461.

McDermott, R. 2002. Experimental Methodology in Political Science. Political Analysis, 10(4), 325-342.

Magaloni, B. 2008. Voting for Autocracy. Hegemonic Party Survival and its Demise in Mexico. Cambridge: Cambridge University Press.

Markedonov, S. 2015. De facto statehood in Eurasia: a political and security phenomenon. Caucasus Survey, 3(3), 195-206.

Nasuti, P. 2016. Administrative Cohesion and Anti-Corruption Reforms in Georgia and Ukraine. Europe-Asia Studies, 68(5), 847-867.

New.on.ge. 2017. Mikheil Saakashvili: Only dead fish follow the stream (aobjom

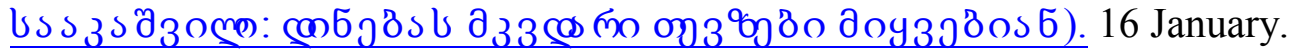

Nodia, G. 2014. The revenge of geopolitics Journal of Democracy, 25(4), 139-150.

Novikova, G. 2017. Armenia: Some features of internal (in)stability. Caucasus Survey, 5(2), 177194.

Ó Beacháin, D. , G. Comai, and A. Tsurtsumia-Zurabashvili (2016) The secret lives of unrecognised states: Internal dynamics, external relations and counter-recognition strategies. Small Wars and Insurgencies, 27(3), 440-466.

Ó Beacháin, D. 2015. Elections without recognition: presidential and parliamentary contests in Abkhazia and Nagorny-Karabakh. Caucasus Survey, 3(3), 239-257.

Ó Beacháin, D. 2012. The dynamics of electoral politics in Abkhazia. Communist and postCommunist Studies, 45, 165-174.

Oskanian, K. 2013. Fear, Weakness and Power in the Post-Soviet South Caucasus. A Theoretical and Empirical Analysis. Basingstoke, Palgrave.

Pepinsky, T. 2014. The Institutional Turn in Comparative Authoritarianism. British Journal of Political Science, 44(3), 631-653.

Prez Oltramonti, G. 2015. The political economy of a de facto state: the importance of local stakeholders in the case of Abkhazia. Caucasus Survey, 3(3), 291-308. 
Polity IV Project. 2015. Political Regime Characteristics and Transitions, 1800-2015. Retrieved on 5 May 2017 from http://www.systemicpeace.org/inscrdata.html

Policy Forum Armenia (PFA). 2013. Corruption in Armenia. Available at from https://www.pfarmenia.org/sites/default/files/documents/files/PFA_Corruption_Report.pdf (accessed 5 May 2017).

Protsyk, O. 2012. Secession and hybrid regime politics in Transnistria. Communist and PostCommunist Studies, 45, 175-182.

Radnitz, S. 2012. Oil in the family: managing presidential succession in Azerbaijan, Democratization, 19(1), 60-77.

Rekhviasvili, L. and A. Polese. 2017. Liberalism and shadow interventionism in postrevolutionary Georgia (2003-2012). Caucasus Survey, 5(1), 1-24.

Saparov, A. 2015. From Conflict to Autonomy in the Caucasus. The Soviet Union and the Making of Abkhazia, South Ossetia and Nagorno Karabakh. London: Routledge.

Stefes, C. 2006. Understanding Post-Soviet Transitions. Corruption, Collusion and Clientelism. Basingstoke, Palgrave.

Shubladze, R. and Ts. Khundadze, Balancing the Three Pillars of Stability in Armenia and Georgia. Caucasus Survey. In this issue.

Smolnik, F. 2012 Political rule and violent conflict: Elections as 'institutional mutation' in Nagorno-Karabakh. Communist and post-Communist Studies, 45, 153-163.

Svolik, M.W. 2013. Learning to love democracy: Electoral accountability and the success of democracy. American Journal of Political Science, 67(3), 685-702.

Sultanova, Sh. 2014. Challenging the Aliyev Regime: Political Opposition in Azerbaijan. Demokratizatsiya: The Journal of Post-Soviet Democratization, 22(1), 15-37.

Turmanidze, K. Promises, lies and the accountability trap. Evidence from a survey experiment in Armenia and Georgia. In this issue.

Von Steinsdorff, S. 2012 Incomplete state-building - incomplete democracy? How to interpret internal political development in the post-Soviet de facto states. Conclusion. Communist and postCommunist Studies, 45, 201-206.

Von Steinsdorff, S. and A. Fruhstorfer. 2012 Post-Soviet de facto states in search of internal and external legitimacy. Introduction. Communist and post-Communist Studies, 45, 117-121.

World Bank. 2016a. World Development Indicators. Retrieved on 5 May 2017 from http://data.worldbank.org/data-catalog/world-development-indicators

World Bank. 2016b. World Governance Indicators. Retrieved on 5 May 2017 from http://data.worldbank.org/data-catalog/worldwide-governance-indicators

Wooden, A.E. and C.H Stefes (eds). 2012. The Politics of Transition in Central Asia and the Caucasus, Enduring Legacies and Emerging Challenges. London: Routledge

Zürcher, C. 2007. The Post-Soviet Wars: Rebellion, Ethnic Conflict, and Nationhood in the Caucasus. New York, NYU Press. 


\section{Appendix. Graphs.}

Graph 1

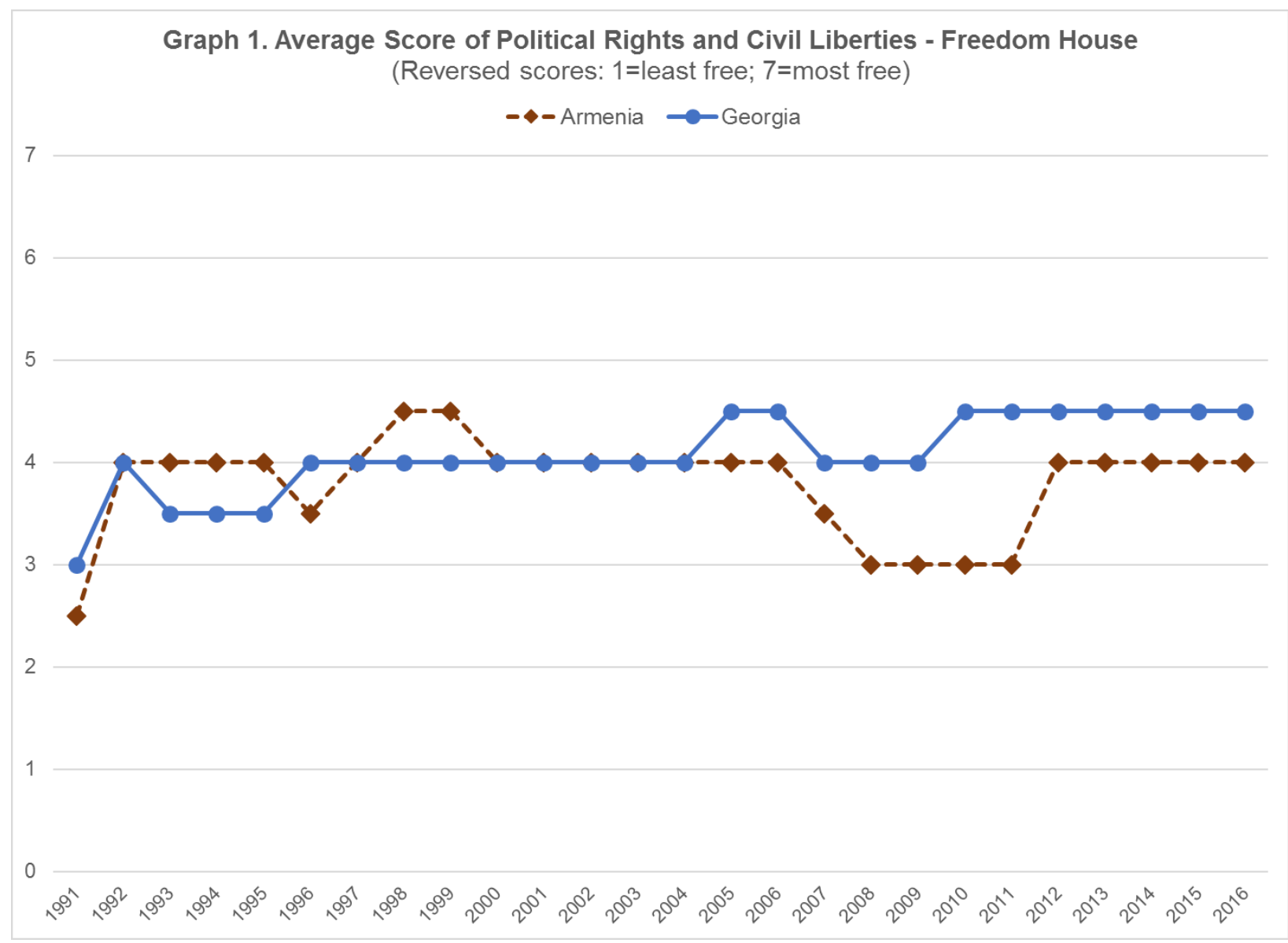




\section{Graph 2}

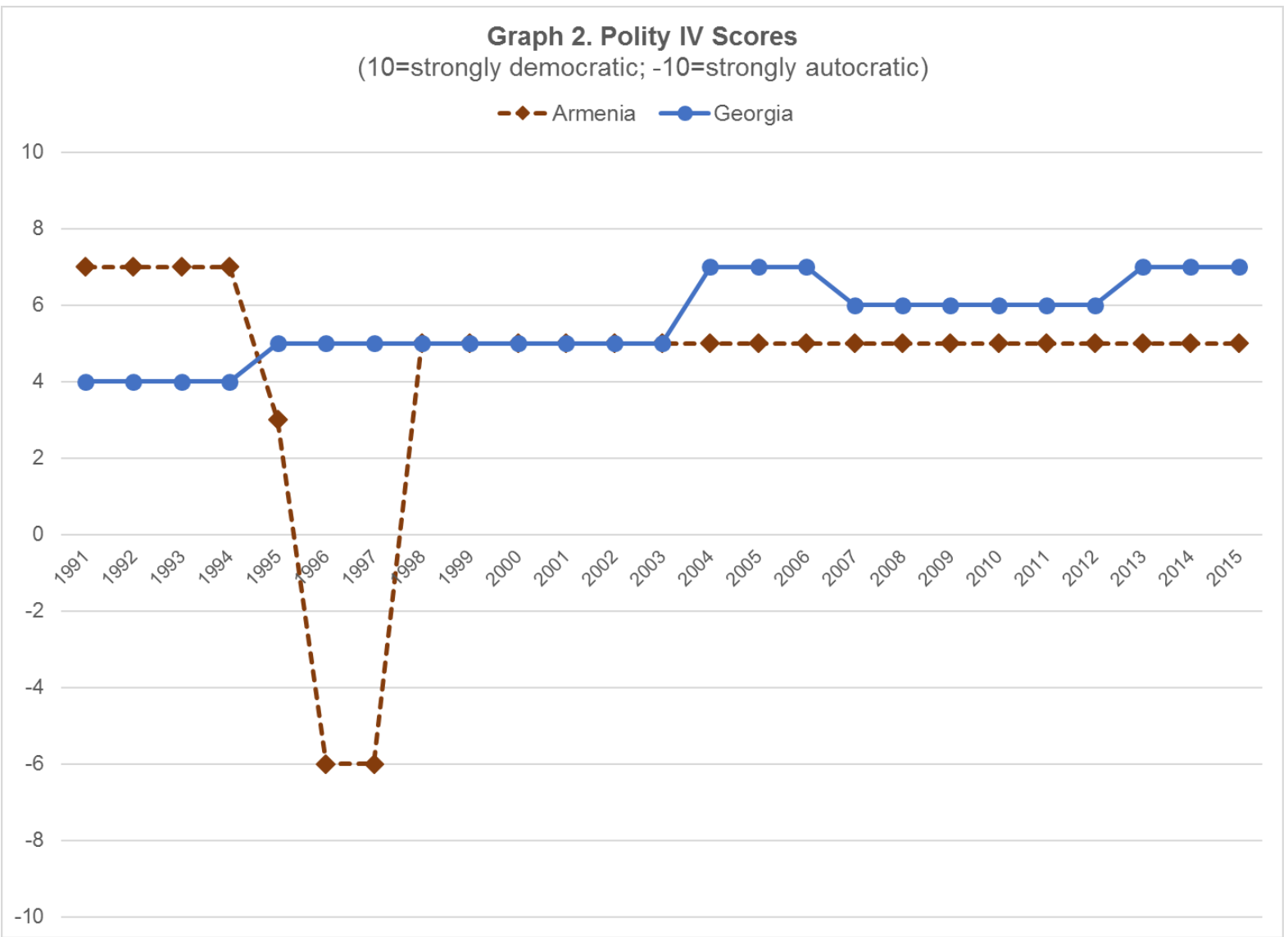




\section{Graph 3}

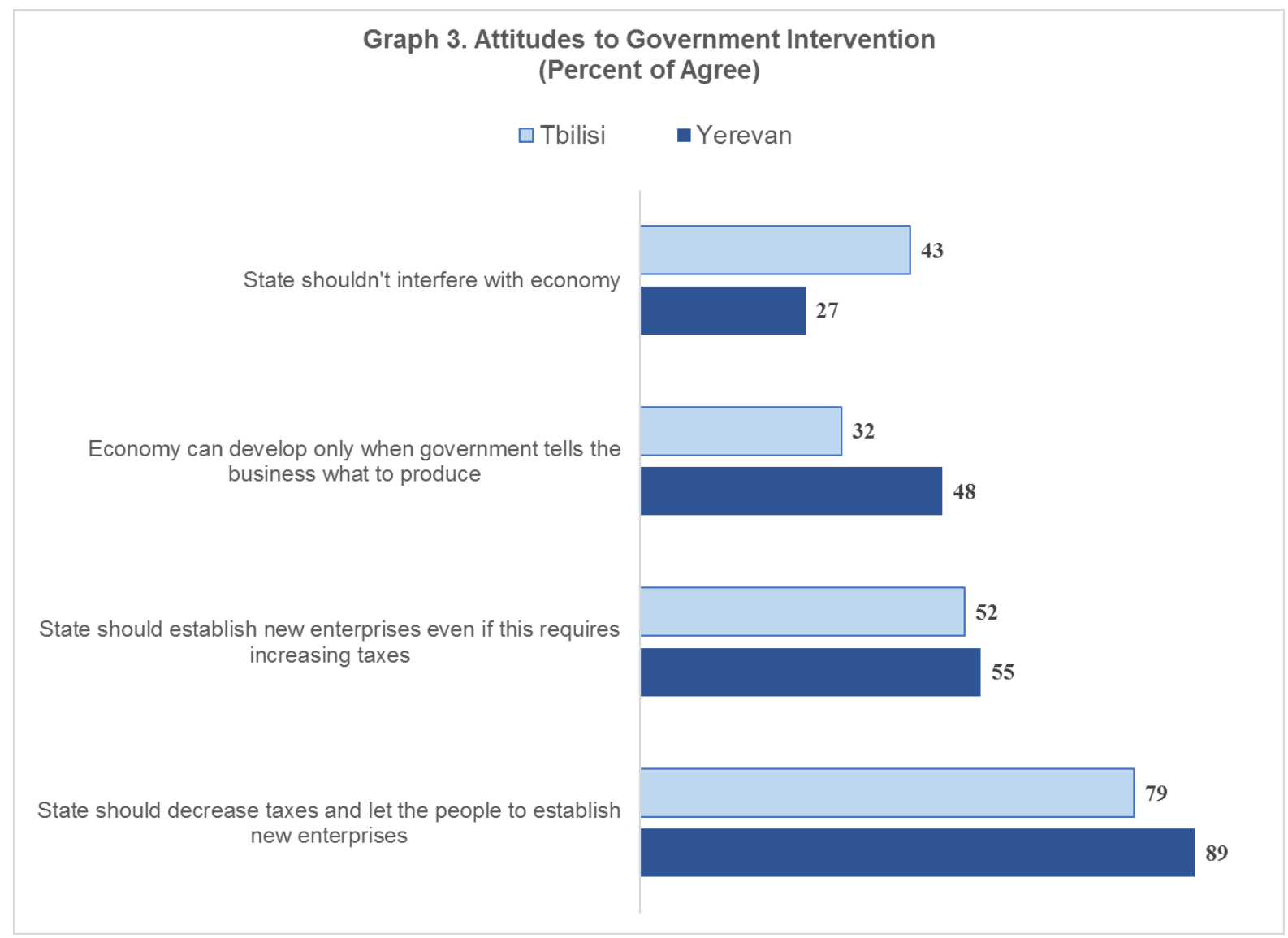




\section{Graph 4a}

Graph 4a. Reported readiness to support the party - All voters

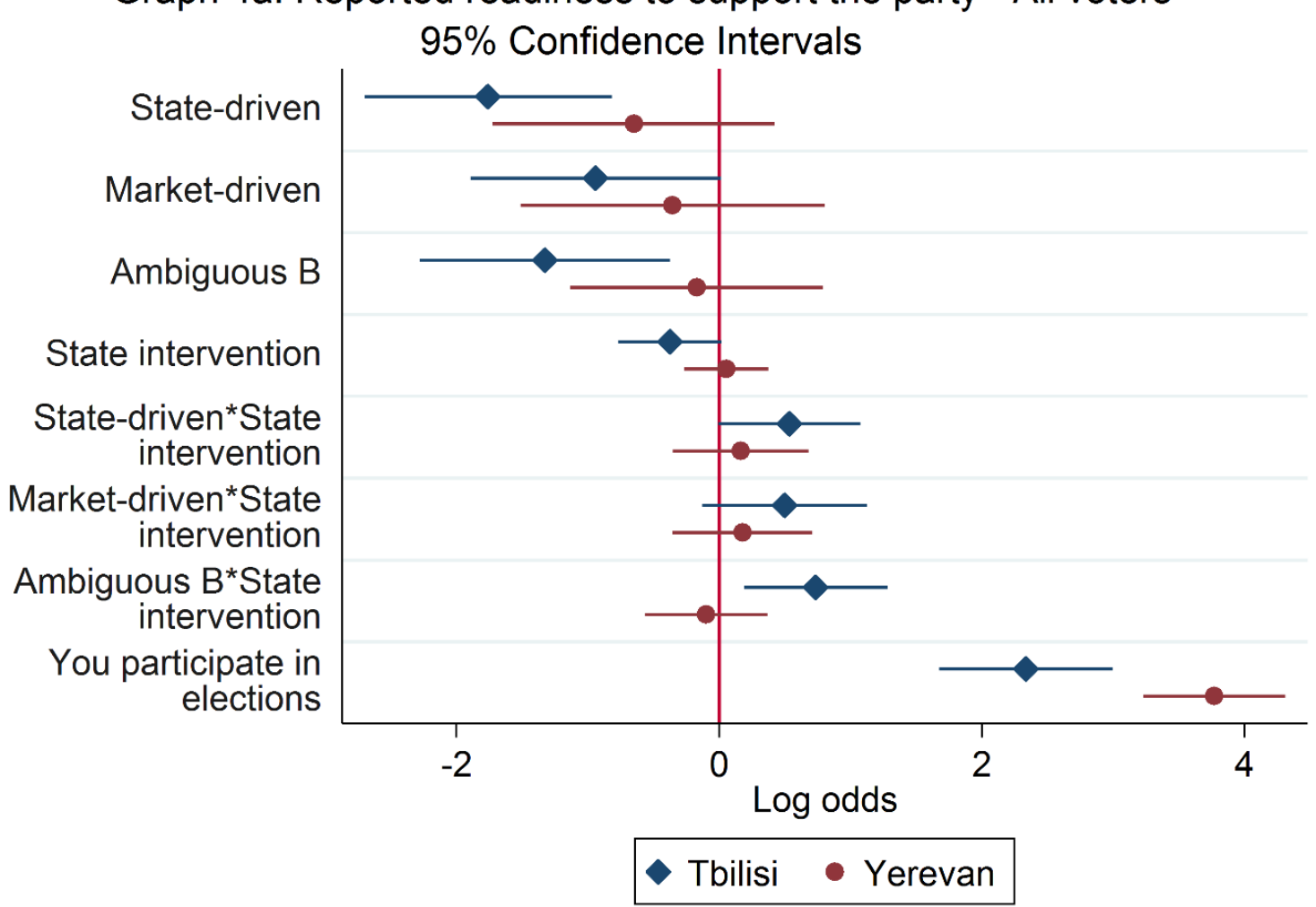




\section{Graph 4b}

Graph 4b. Expected vote share of the party - All voters 95\% Confidence Intervals

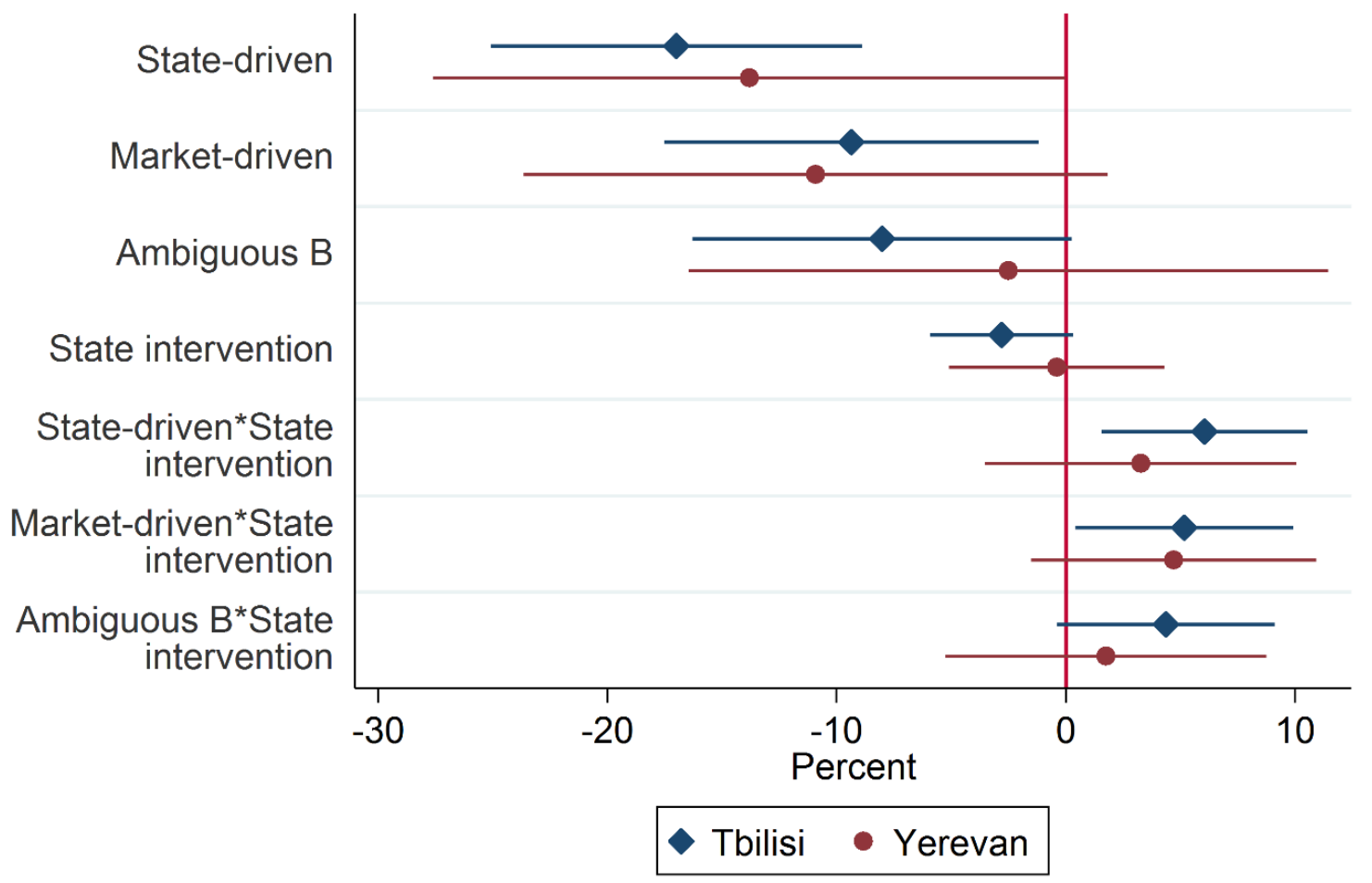




\section{Graph 5}

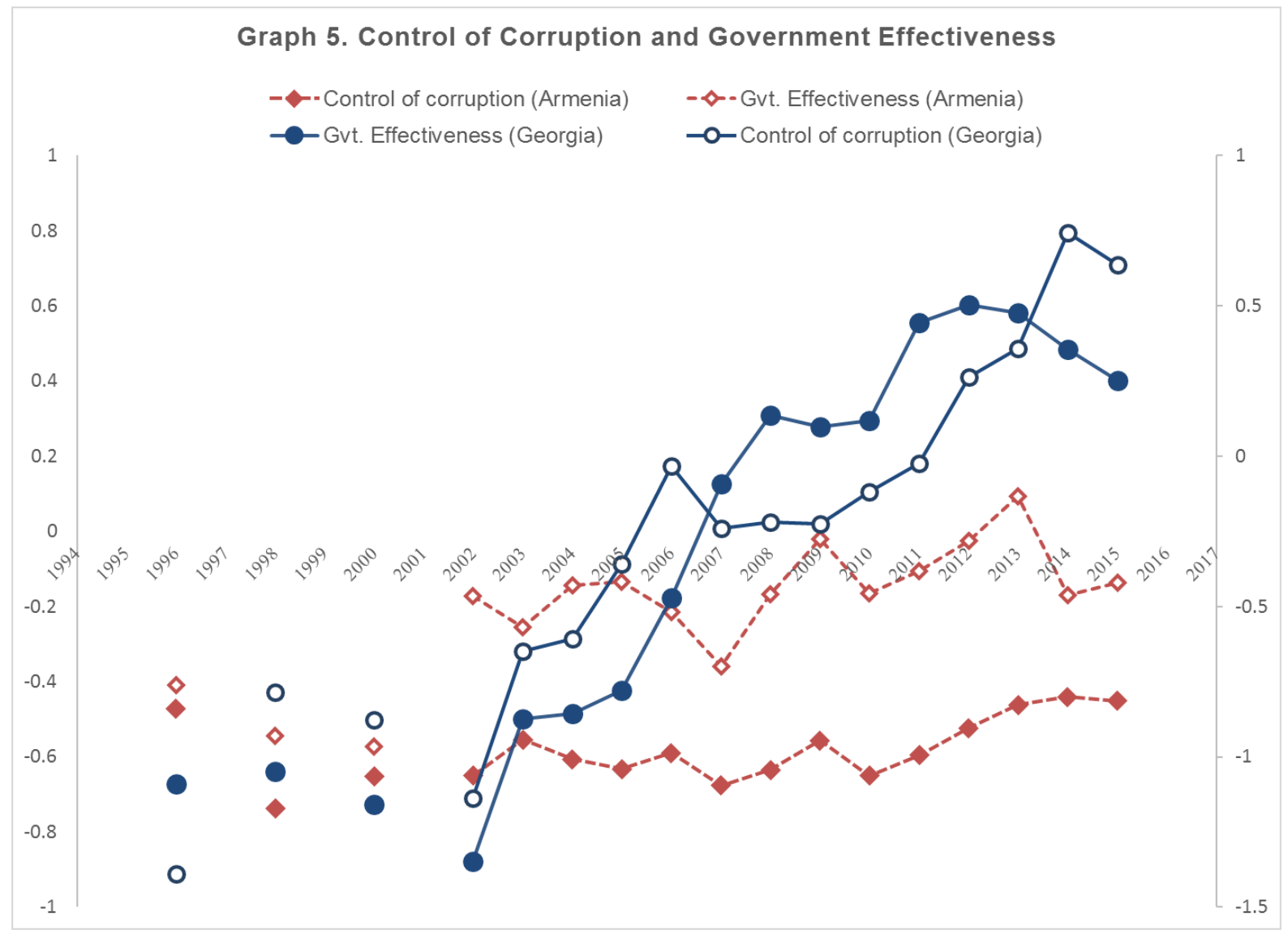

